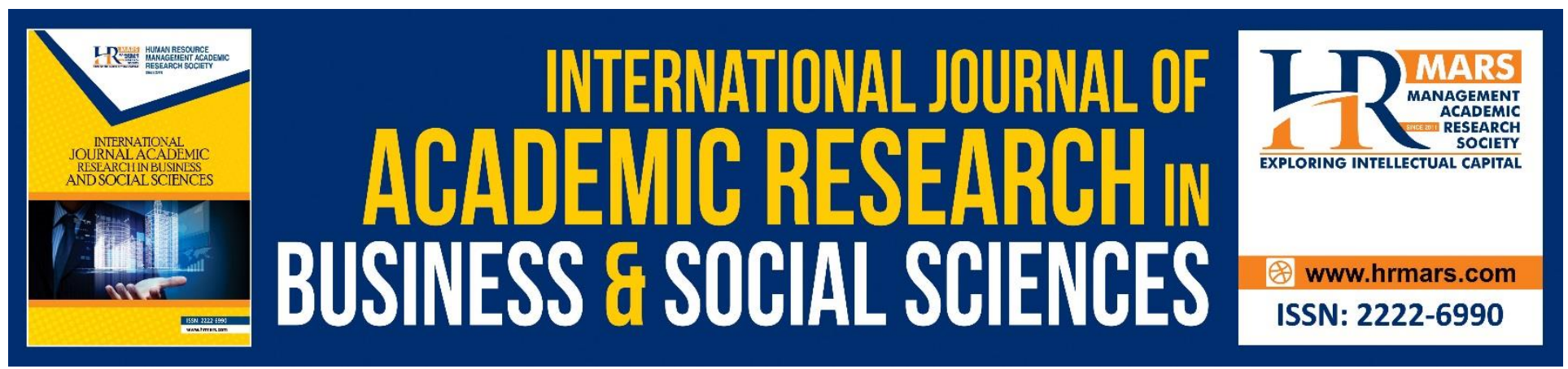

\title{
Return, Volatility and Equity Fund Flows Linkages: Evidence from an Emerging Market
}

\section{Ros Zam Zam Sapian, Jing Quan Lee}

To Link this Article: http://dx.doi.org/10.6007/IJARBSS/v8-i7/4333

DOI: $10.6007 /$ IJARBSS/v8-i7/4333

Received: 02 June 2018, Revised: 07 June 2018, Accepted: 29 June 2018

Published Online: 18 July 2018

In-Text Citation: (Sapian \& Lee, 2018)

To Cite this Article: Sapian, R. Z. Z., \& Lee, J. Q. (2018). Return, Volatility and Equity Fund Flows Linkages: Evidence from an Emerging Market. International Journal of Academic Research in Business and Social Sciences, 8(7), 172-186.

Copyright: (C) 2018 The Author(s)

Published by Human Resource Management Academic Research Society (www.hrmars.com) This article is published under the Creative Commons Attribution (CC BY 4.0) license. Anyone may reproduce, distribute, translate and create derivative works of this article (for both commercial and non-commercial purposes), subject to full attribution to the original publication and authors. The full terms of this license may be seen at: http://creativecommons.org/licences/by/4.0/legalcode

\section{Vol. 8, No. 7, July 2018, Pg. 172 - 186}

Full Terms \& Conditions of access and use can be found at http://hrmars.com/index.php/pages/detail/publication-ethics 


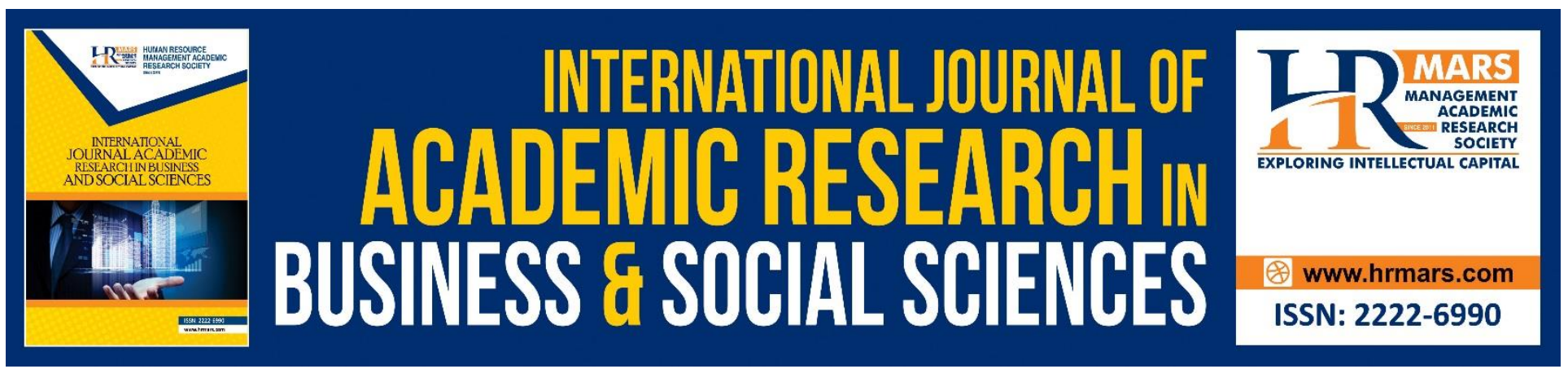

\title{
Return, Volatility and Equity Fund Flows Linkages: Evidence from an Emerging Market
}

\author{
Ros Zam Zam Sapian, Jing Quan Lee \\ Faculty of Economics and Management, Universiti Kebangsaan Malaysia, UKM Bangi, Selangor, \\ Malaysia \\ Email: zamzam@ukm.edu.my
}

\begin{abstract}
This study examines the dynamic linkages among market return, market volatility, and equity fund flows of institutional and retail investors both foreign and local into Malaysian Stock Exchange, Bursa Malaysia. Using a total of 1661 daily observations of aggregate trade data for a period from $1^{\text {st }}$ October 2009 to $30^{\text {th }}$ June 2016, this study finds that market return has an effect on buy trades of local investors, sell trades of foreign institutions and local retailer as well as net flows of foreign institutions and retailers. On the equity flows-market return relation, the finding shows that the buy trades of foreign retail investors, net flows of foreign institutions and foreign retailers affect market return. This study also provide evidence that market volatility is significantly impact foreign institutional investors buy trades as well as local retailer net flows of equity. Furthermore, this study reveal that there are insignificant results for the equity flows-market volatility relation. The findings of this study is crucial and will benefit most to portfolio fund managers, traders, foreign and local investors dealing with Bursa Malaysia.
\end{abstract}

Keywords: Market Return, Market Volatility, Equity Fund Flows, Institutional And Retail Investors, Granger Causality

\section{Introduction}

Equity fund flows have been a typical indicator used by investors and market speculators to gauge other investors' behaviour or market sentiments. The changes in fund flows reflect the changes in market sentiments. It has been a nature that security market roller-coaster would never stop, and for that reason, market return and market volatility among others, have been caused of concern for global investors as determinants of investment decisions. Finance literature also demonstrates that different arrays of investors engage with different trading styles of which may affect market price and/or volatility differently. For instance, a study by Bae et al. (2008) state investors trading styles might lead to further increases in prices or greater volatility. This is due to momentum traders demand liquidity as price increases. 
There are ample empirical studies on the relations between market return and fund flows of equity, and document two main findings. Firstly, return of the market has an impact on equity flows. Prior literature supports the positive association between return of the market and equity flows in large number of the studies (Froot et al. 2001; Jinjarak et al. 2011). Moreover, there is dissimilar trading behaviour of fund flows to market return and volatility between countries (Paek 2014). Secondly, fund flows of equity also have an effect on market return. Past studies that show fund flows of equity have an impact on market return includes Bekaert et al. (2002), Dahlquist and Robertsson (2004) and French and $\mathrm{Li}$ (2012). Hence, prior studies show the existence of bidirectional relationships between market return and fund flows of equity. Stock return volatility is fundamental to finance. There are also many studies have been carried out on the relationships between market return volatility and fund flows of equity. The findings of past studies show that there is an association between market volatility and fund flows of equity, and vice versa (Lee et al. 2015; Cao et al. 2008; Nguyen and Le 2013).

Even though many studies have been carried out on the relations between market return, market volatility and equity flows on developed market, the same area of study has been relatively underexplored for the Malaysian equity market. Hence, it is crucial to research the dynamic linkages among market return, market volatility, and equity fund flows of which is the focus of this study. This study aims to present a new understanding on the relationships among market return, market volatility, and equity fund flow of an emerging equity market, Bursa Malaysia which is the official stock exchange of Malaysia. This study would like to answer the subsequent two research questions: First, does return of the equity market affects equity fund flows or vice versa? Second, does volatility of the equity market affects equity fund flows or vice versa? The findings of this paper contributes to the limited empirical literature on investors trading behaviour particularly for emerging equity market.

The findings of this study are beneficial to various parties such as equity investors, fund managers and policymakers of emerging markets like Malaysian equity market. Understanding the behavior of equity flows is crucial to both investors and fund managers as this will assist them to develop better tactical investment strategies to maximize return. A sudden capital outflow by equity investors particularly foreign investors may dampen and destabilize local equity markets particularly during periods of recessions (Tsai 2009) or period of financial upheaval. Thus, it is crucial to have a better knowledge on the investors trading behaviour in order to meet any unanticipated events. Not only that, having a better knowledge on the investors trading behaviour may assist the local authority to enhance its equity market liquidity and consequently stocks marketability among investors.

The remainder of this paper is as follows: Section 2 presents the literature review, Section 3 presents the data and methodology and the tested hypothesis. Section 4 presents the results while Section 5 provides the summary and conclusions of this study.

\section{Literature Review}

Finance literature documents voluminous studies on the linkages between market return and fund flows of equity. Furthermore, different arrays of investors are perceived to engage with different trading styles of which may affect market price and/or volatility differently. For example, a study by Bae, Yamada and Ito (2008) reveal that investors' trading styles may cause prices to increase further or volatility to become greater. This is due to momentum traders who demand liquidity when there 
INTERNATIONAL JOURNAL OF ACADEMIC RESEARCH IN BUSINESS AND SOCIAL SCIENCES Vol. 8, No. 7, July 2018, E-ISSN: 2222-6990 @ 2018 HRMARS

is an increase in prices. The behavior of investors' trading differs not only intra but also inter equity markets. For instance, Paek and Ko (2014) documents different trading pattern of equity fund flows to market return and volatility between countries.

Previous studies show mixed results on the relations between return of market and equity fund flows. Earlier studies which focus on the linkages between market return and aggregate mutual fund flow includes a study by Warther (1995) which shows that there is a negative relation between returns and subsequent flows. Edelen and Warner (2001) also find a very strong relation between return and fund flows. Even though in general investors take an overnight period to react, their study reveal that lagged return has an impact on flows. Furthermore, Cha and Kim (2010) and Kim and Kim (2016) find evidence that there is a positive unidirectional causal relation from stock return to fund flows at a macro level. Mishra (2011) conducts a similar study in India and his finding supports empirical evidences that there is a unidirectional causal relation from stock market return to mutual funds investment. In another study, Watson and Wickramanayake (2012) state that share market returns Granger-cause managed fund flows in Australia. Oh and Parwada (2007) study the relationship between fund flows and stock market returns in Korea. They find that in terms of net trading flows, mutual fund investors are contrarian traders. Moreover, Ha et al. (2015) demonstrate that market return shocks have a contemporaneous positive effects on cash inflows while little effect of on cash outflows.

Meanwhile, in the context of Greece capital market, studies by Caporale et al. (2004) and Alexakis et al. (2005) find that there is a bidirectional causal relation between mutual fund flows and stock returns. A study by Aydogan et al. (2014) reveals similar finding on Turkish capital market. BenRephael et al. (2011) on the other hand reveal that lagged returns do not have an impact on mutual fund flows. French and Naka (2013) obtain similar findings. Their study reveals an insignificant impact of market return on U.S. equity inflows into China and India markets. Instead, the U.S. investors attract to the China and Indian market is based on the unique characteristics and fundamental values of these two countries. Another study by Richards (2005) examines the investors trading patterns of six Asian emerging equity markets on daily basis. The findings reveal that individual and foreign investors execute different trading strategies. Foreign investors tend to be momentum traders. On the other hand, individual investors and less sophisticated institutions tend to be contrarians. On the Malaysian equity market perspective, there exists a positive association between market return and fund flows of equity in finance literature. The studies include Bekaert et al. (2002), Bohn and Tesar (1996), Froot and Ramadorai (2008), Froot et al. (2001), Jinjarak et al. (2011), Lin and Swanson (2004), Lin and Swanson (2008) and Sapian and Auzairy (2015).

Prior literature also documents the presence of flow-return relationship in equity market. For instance, Warther (1995) find evidence of a positive relationship between flows and subsequent returns. Edelen and Warner (2001) examine the relationship between market returns and aggregate equity flow by using daily flow data of U.S. equity. Evidence of their study reveals an association between the variables which the causality running from fund flows to market return. Ben-Rephael et al. (2011) also find similar results whereby lagged flows seem to predict future returns. Other studies that show a significant impact of fund flows on market return includes Bekaert et al. (2002), Dahlquist and Robertsson (2004), French and Li (2012), Froot and Ramadorai (2008), Froot et al. (2001) and Ülkü and ikizlerli (2012). Chandra (2012) study also provides similar findings, but the associations are 
INTERNATIONAL JOURNAL OF ACADEMIC RESEARCH IN BUSINESS AND SOCIAL SCIENCES Vol. 8, No. 7, July 2018, E-ISSN: 2222-6990 @ 2018 HRMARS

only in short period of time. In short, prior studies provide evidences of bi-directional relationships between market returns and fund flows of equity.

All of the above mentioned studies focus on the dynamic relationship between market returns and equity fund flows. However, prior literature also provides evidences that there is an association between equity flows and market return volatility. High market return volatility reflects higher risk and uncertainty which may dampen a country's economic performance. Most of the studies show the direction of causality running from fund flows of equity to market volatility. For instance, Lin (2006) demonstrates that foreign investors' investment decisions affect market volatility significantly across time as foreigners play an increasing important role in Taiwan's market. Pavabutr and Yan (2007) investigate the impact of foreign portfolio flows on the volatility of Thailand stock market. Their study reveals that foreign flows have an effect on market return volatility of which due mainly by the unexpected shocks to foreign flows. Using a VAR approach, Cao et al. (2008) document a negative correlation between volatility and concurrent and lagged flow. A shock in inflow foresees a decrease in volatility, while a shock in outflow foresees an increase in volatility.

Bae et al. (2008) examine the trading impact of various investor types on return volatility of equity. The findings of their study reveal that the interactions of momentum and contrarian investors trades affect market volatility. Market volatility increases above the average level when there is greater momentum buy trades and less contrarian sell trades. The momentum investors are said to demand liquidity while the contrarian or profit-taking investors to supply liquidity. On the other hand, volatility diminishes by more than half, when there are greater sell trades by contrarian investors and less buy trades by momentum investors. Nguyen and Le (2013) analyse the impacts of daily foreign flows on Vietnamese stock market volatility and find that foreign flows have an impact on market volatility but only on short term basis.

Li and Wang (2010) examine a short run dynamic relation between trades of institutional investors and stock price volatility in a retail investor-dominated emerging market. They find that there is a negative relation between volatility and net institutional trades which is significant. Moreover, the findings show that volatility and institutional trade relationship differs for buy and sale trades, and for small and large stocks. Ahmed (2016) examines the relationship between market volatility and equity flows of foreign and local investors' trading activities in Qatar Stock Exchange. His study demonstrates that sales of foreign institutions and individuals have a positive impact on market volatility while purchases of foreign institutions tend to reduce market volatility. On the contrary, purchases of local institutions impact market volatility negatively while sales of local institutions have no impact on volatility. Another study by Umutlu, Akdeniz and Salih (2013) demonstrate that there is a positive relation between volatility and foreign investors net equity flows even after controlling for market-wide price impacts, market development, liquidity and persistency in volatility. Wang (2007) study documents strong contemporaneous relationship between foreign equity trading and market volatility in Indonesia and Thailand and foreign sale trades explain most for the market volatility in both countries.

Past studies that document market volatility-fund flows relationships among others are Paek and Ko (2014) and Lee et al. (2015). Paek and Ko (2014) explores the dynamic relationships between market volatility, market return and equity flows of both U.S. and Japan equity market. The result of their 
INTERNATIONAL JOURNAL OF ACADEMIC RESEARCH IN BUSINESS AND SOCIAL SCIENCES Vol. 8, No. 7, July 2018, E-ISSN: 2222-6990 @ 2018 HRMARS

study demonstrates the existence of a positive feedback trading for the U.S. and Japan market, however with completely different causality. The result reveals that the positive feedback trading is due to the negative effect of lagged market return on outflows for the U.S. market and the positive effect of market return on inflows for the Japan market. Furthermore, there is a negative contemporaneous effect of market volatility shocks on net flows for the U.S. market. There is a positive (negative) contemporaneous effect of return shocks on net flows for the U.S (Japan) respectively. The findings also reveal that volatility shocks rather than return shocks explain more the cash flows for the U.S. market, and there is an opposite result for the Japan market. Lee et al. (2015) examine the dynamic relations among market volatility, market return, and aggregate equity fund flows on a monthly basis in an international context. Their findings among others show that Western investors give emphases on market volatility when they buy and redeem equity funds. Cao et al. (2008) also find similar findings. Their study shows that there is a negative impact of volatility on daily mutual fund flows. Another study by $\mathrm{Ha}$ et al. (2015) demonstrates that market volatility shocks affect cash outflows (net flows) in positive (negative) way contemporaneously. However, the impact of market volatility shocks on inflows is very minimal. In short, prior studies also documents mixed results on the market volatility-fund flows relations.

\section{Data and Methodology}

\section{Measurement of Market Return, Market Volatility and Net Flows}

This study employs time series data of market return, market volatility and equity flows. The time series data is from $1^{\text {st }}$ October 2009 to $30^{\text {th }}$ June 2016, of which in total comprises of 1661 number of observations to examine the relationships among market return, market volatility and equity flows. This study focuses mainly on three variables which are market return, market volatility and equity flows in the form of trades quantity (buy trades, sell trades and net flows). Table 1 presents the descriptions of the abbreviations for the above three main variables utilize in this study.

Table 1. Abbreviations

\begin{tabular}{|c|c|c|c|}
\hline Variables & Abbreviations & Variables & Abbreviations \\
\hline \multicolumn{2}{|c|}{$\begin{array}{c}\text { Foreign Equity Flows } \\
\end{array}$} & \multicolumn{2}{|c|}{ Local Equity Flows } \\
\hline Institutions & & Institutions & \\
\hline Buy Trades & FIBUY & Buy Trades & LIBUY \\
\hline Sell Trades & FISELL & Sell Trades & LISELL \\
\hline Retail & & Retail & \\
\hline Buy Trades & FRBUY & Buy Trades & LRBUY \\
\hline Sell Trades & FRSELL & Sell Trades & LRSELL \\
\hline Net Flows & & Net Flows & \\
\hline Institutions & NFFINST & Institutions & NFLINST \\
\hline Retail & NFFRET & Retail & NFLRET \\
\hline Market Return & RET & Market Volatility & RETVOL \\
\hline
\end{tabular}

This study employs Equation (1) to compute daily market return. 
INTERNATIONAL JOURNAL OF ACADEMIC RESEARCH IN BUSINESS AND SOCIAL SCIENCES

Vol. 8, No. 7, July 2018, E-ISSN: 2222-6990 @ 2018 HRMARS

where

$$
R_{t}=\left(P_{t}-P_{t-1}\right) / P_{t-1}
$$

$\mathrm{R}_{\mathrm{t}}=$ Daily market return,

$P_{t}=$ Closing price of market index on day $t$, and

$\mathrm{P}_{\mathrm{t}-1}=$ Closing price of market index on day $\mathrm{t}-1$

Consistent with Giles (2008), this study uses return squared as a proxy for market volatility.

While, this study employs Equation (2) to compute daily net flows in the form of quantity of trades.

where

$$
F_{t}=\frac{\left(V_{B u y}-V_{\text {Sell }}\right)}{\left(V_{\text {Buy }}+V_{\text {Sell }}\right)}
$$

$$
\begin{aligned}
F_{\mathrm{t}} & =\text { Daily net flows, } \\
\mathrm{V}_{\text {Buy }} & =\text { Quantity of buy trades, and } \\
\mathrm{V}_{\text {Sell }} & =\text { Quantity of sell trades }
\end{aligned}
$$

\section{Unit Root}

Before proceeds with VAR Granger Causality test, this study adopts a unit root test to ensure that all of the time series data are stationary. This study employs Augmented Dickey Fuller (ADF) test (Dickey and Fuller $(1979 ; 1981)$ to determine the stationarity of market returns, market volatility and fund flows data. This study will not be able to carry out further analysis using Vector Autoregressive (VAR) model if the variables have been found to be not stationary. The null hypothesis to test the stationarity of the data is that the variable contains a unit root which means the time series data are not stationary, and the alternative hypothesis is that the variable has no unit root. Moreover, this study employs Akaike information criterion (AIC) for the determination of the appropriate number of lag length.

\section{VAR Granger Causality}

This study employs VAR Granger Causality test to examine the dynamic relationships between market return and equity fund flows, and between market volatility and equity fund flows. Consistent with Darwish (2012), a VAR model which includes market returns and equity fund flows is as follows:

$$
\begin{aligned}
& R_{t}=\alpha_{R}+\sum_{\mathrm{i}=1}^{\mathrm{n}} \alpha_{i} R_{t-i}+\sum_{i=1}^{n} \beta_{i} F_{t-i}+\varepsilon_{R, t} \\
& F_{t}=\alpha_{F}+\sum_{\mathrm{i}=1}^{\mathrm{n}} \alpha_{i} F_{t-i}+\sum_{i=1}^{n} \beta_{i} R_{t-i}+\varepsilon_{F, t}
\end{aligned}
$$

While, a VAR model which includes market volatility and net flows is as follows:

$$
\begin{aligned}
& V_{t}=\alpha_{V}+\sum_{\mathrm{i}=1}^{\mathrm{n}} \alpha_{i} V_{t-i}+\sum_{i=1}^{n} \beta_{i} F_{t-i}+\varepsilon_{V, t} \\
& F_{t}=\alpha_{F}+\sum_{\mathrm{i}=1}^{\mathrm{n}} \alpha_{i} F_{t-i}+\sum_{i=1}^{n} \beta_{i} V_{t-i}+\varepsilon_{F, t}
\end{aligned}
$$

where $R_{t}$ is market return, $F_{t}$ is Buy Trades, Sell Trades or Net Flows in the form of quantity of trades and $V_{t}$ represent market volatility, $\varepsilon_{R, t}, \varepsilon_{F, t}$ and $\varepsilon_{V, t}$ are orthogonal error terms and $\mathrm{n}$ indicate autoregressive lag lengths. 
INTERNATIONAL JOURNAL OF ACADEMIC RESEARCH IN BUSINESS AND SOCIAL SCIENCES

Vol. 8, No. 7, July 2018, E-ISSN: 2222-6990 (C) 2018 HRMARS

The null hypothesis in Granger causality is that $F_{t}$ does not Granger-cause $R_{t}$ in Equation (3). The null hypothesis for Equation (4) is that $R_{t}$ does not Granger-cause $F_{t}$. Likewise, the null hypothesis of Equation (5) and Equation (6) is that $F_{t}$ does not Granger-cause $V_{t}$ and $V_{t}$ does not Granger-cause $F_{t}$ respectively. The null hypothesis above can be addressed by $\mathrm{H}_{0}: \beta_{i}=0$ for all $i$ in stated equation and the test statistic is a Chi-square test. Rejection of null hypothesis supports the presence of Granger causality between the variables.

\section{Results and Discussions}

\section{Descriptive Statistics}

Table 2 reports the summary of descriptive statistics of buy and sell trades, net flows, market return and market volatility. The statistics show that local retailers contribute the most to the trading volume, followed by local institutions and then foreign institutions. This support the conjecture that Malaysian equity market is retail investors dominated market. The average net flows of foreign and local investors are negative except for local retailers. This means that foreign investors both institutional and retail as well as local institutional investors sell more than buy of domestic shares.

Table 2. Descriptive Statistics of Daily Market Return, Market Volatility and Equity Flows

\begin{tabular}{lcccccc}
\hline Variable & Mean & Std. Dev. & Skewness & Kurtosis & $\begin{array}{c}\text { Jarque- } \\
\text { Bera }\end{array}$ & ADF \\
\hline FIBUY & 127.653 & 61.722 & 3.080 & 29.302 & $49716.07^{* *}$ & $-6.446^{* *}$ \\
FISELL & 134.803 & 70.138 & 2.683 & 25.245 & $35674.28^{* *}$ & $-4.958^{* *}$ \\
FRBUY & 11.339 & 5.316 & 1.512 & 7.967 & $2305.05^{* *}$ & $-9.780^{* *}$ \\
FRSELL & 11.566 & 5.936 & 1.674 & 9.174 & $3361.17^{* *}$ & $-8.905^{* *}$ \\
LIBUY & 258.437 & 132.019 & 1.312 & 7.071 & $1598.42^{* *}$ & $-4.081^{* *}$ \\
LISELL & 259.121 & 127.295 & 1.476 & 8.483 & $2642.23 * *$ & $-4.509^{* *}$ \\
LRBUY & 751.630 & 347.644 & 1.255 & 8.115 & $2212.48^{* *}$ & $-6.274^{* *}$ \\
LRSELL & 728.373 & 329.166 & 1.180 & 7.408 & $1703.62 * *$ & $-6.262^{* *}$ \\
NFFINST & -0.017 & 0.137 & -0.049 & 3.063 & $0.94 * *$ & $-7.118^{* *}$ \\
NFFRET & -0.0008 & 0.197 & 0.126 & 3.523 & $23.004^{* *}$ & $-34.849 * *$ \\
NFLINST & -0.007 & 0.072 & -0.235 & 4.458 & $159.99 * *$ & $-9.346^{* *}$ \\
NFLRET & 0.013 & 0.026 & 0.204 & 5.484 & $432.02 * *$ & $-22.677^{* *}$ \\
RET & 0.0002 & 0.005 & -0.202 & 5.351 & $387.85^{* *}$ & $-36.146^{* *}$ \\
RETVOL & $3.46 E-$ & $7.19 E-05$ & 5.699 & 56.022 & $200376^{* *}$ & $-21.396^{* *}$ \\
\hline
\end{tabular}

Note: $* *$ Significant at $1 \%$ level

The Jarque-Bera normality test indicates that all of the variables are not normally distributed. The findings in Table 2 also report the results of ADF test for unit root. The results show that the null hypothesis where variables mentioned are non-stationary at level is all rejected. Thus, further analysis using VAR Granger causality test is permissible. 
INTERNATIONAL JOURNAL OF ACADEMIC RESEARCH IN BUSINESS AND SOCIAL SCIENCES

Vol. 8, No. 7, July 2018, E-ISSN: 2222-6990 @ 2018 HRMARS

\section{Correlation Coefficients}

Table 3 presents the correlation coefficients between market return and equity net flows, and between market volatility and equity net flows. The results in Table 3 demonstrate that market return is negatively correlated with net flows of foreign retailers, local institutions and local retailers with the correlation of $-0.147,-0.127$ and -0.203 respectively at a significance level of $1 \%$.

Table 3. Spearman Correlation Coefficients between Market Return, Market Volatility and Net Flows.

\begin{tabular}{lcccccc}
\hline Variable & NFFINST & NFFRET & NFLINST & NFLRET & RET & RETVOL \\
\hline NFFINST & - & & & & & \\
NFFRET & $-.098^{* *}$ & - & & & & \\
NFLINST & $-.527^{* *}$ & -.019 & - & & & \\
NFLRET & $-.387^{* *}$ & $.053^{*}$ & $-.203^{* *}$ & - & & - \\
RET & $.264^{* *}$ & $-.147^{* *}$ & $-.127^{* *}$ & $-.203^{* *}$ & - & \\
RETVOL & $-.053^{*}$ & $.075^{* *}$ & $.050^{*}$ & .038 & $.065^{* *}$ & \\
\hline
\end{tabular}

Note: ** Significant at $1 \%$ level, * Significant at $5 \%$ level. This study uses Spearman Correlation test

due to the non-normality of the time series data.

The Spearman correlation between market return and net flows of foreign institutions is 0.264 which indicates that a positive relationship exists between these two variables. The statistics in Table 3 also reports that market volatility is positively correlated to net flows of foreign retailers, local institutions and local retailers with correlation of $0.075,0.050$ and 0.038 respectively. The Spearman correlation between market volatility and net flows of foreign institutions is -0.053 , which means that when market volatility increase, net flows of foreign institutions decrease. This is contrary to the study of Umutlu Akdeniz and Altay-Salih (2013) where they find that there is a positive relationship between average total volatility and foreign investors' net equity flow. In addition, the results in Table 3 reveal that there is inverse relationship for the correlations between market return and net flows; and market volatility and net flows for all categories of investors.

\section{VAR Granger-Causality Test}

The earlier section shows that there is a correlation between market return, market volatility; and net flows but these correlations do not necessarily mean that there is a causal relation between the variables. This section reports the results of Granger causality between market return and equity fund flows, and between market volatility and equity fund flows according to VAR framework as per Table 4 and 5 respectively.

\section{Relationship between Market Return and Equity Flows}

This section reports the causal relation between market return and equity fund flows of foreign and local investors, both institutional and retail. The findings in Panel A, B and C of Table 4 show the return-flows relation in terms of buy trades, sell trades and net flows respectively. 
INTERNATIONAL JOURNAL OF ACADEMIC RESEARCH IN BUSINESS AND SOCIAL SCIENCES Vol. 8, No. 7, July 2018, E-ISSN: 2222-6990 @ 2018 HRMARS

The findings demonstrate that the testing hypothesis that 'market return does not granger-cause equity flows' is rejected for the buy trades of local institutions, local retailers; and the sell trades of both foreign institutions and local retailers at significance level of $1 \%$ and $5 \%$ respectively. These findings suggest that market return has an impact on local institutions and retail equity purchases. Moreover, market return also impacts the sell trades of foreign institutions and local retailers. The results also report the rejection of the null hypothesis that 'equity flows do not granger-cause market return' for the buy trades of foreign retailers. These results signify that there is a significant impact of foreign retail investor buying activities on market returns.

This study extends the analysis on the market-flows causal relations but this time is between market return and net flows. The results in Panel $\mathrm{C}$ illustrate that the null hypothesis that 'market return does not granger-cause net flows' is rejected for both net flows of foreign institutions and retailers at the significance level of $1 \%$ respectively. These findings signify that market return significantly affect net flows of both foreign institutions and retailers. Adaoglu and Katircioglu (2013) find that stock returns affect net foreign investor flows on a monthly basis for the pre-EU accession negotiations period which is consistent with the findings of this study. Ahmed (2016) demonstrate that Qatari market daily returns granger cause individual and institutional investment flows of both local and foreign investors. Based on weekly frequency data, French (2011) establishes significant relationship between past market return and foreign flows for South Africa equity market. Another study by Hong and Lee (2011) shows that Korean market return affects institutional, individual and foreign investors net investment flows.

Table 4. Granger-Causality Test between Market Return and Equity Flows

\begin{tabular}{|c|c|c|c|c|}
\hline \multirow[t]{2}{*}{ Equity Flows } & \multicolumn{2}{|c|}{$\begin{array}{c}\text { Market Return does not } \\
\text { Granger-cause Equity Flows }\end{array}$} & \multicolumn{2}{|c|}{$\begin{array}{c}\text { Equity Flow does not } \\
\text { Granger-cause Market Return }\end{array}$} \\
\hline & Chi-sq & Prob. & Chi-sq & Prob. \\
\hline \multicolumn{5}{|l|}{ Panel A: Buy Trades } \\
\hline Foreign Institutions & 0.180 & 0.913 & 4.310 & 0.115 \\
\hline Foreign Retailers & 3.802 & 0.149 & 7.060 & $0.029 *$ \\
\hline Local Institutions & 12.962 & $0.001^{* *}$ & 3.070 & 0.215 \\
\hline Local Retailers & 5.970 & $0.050^{*}$ & 1.605 & 0.448 \\
\hline \multicolumn{5}{|l|}{ Panel B: Sell Trades } \\
\hline Foreign Institutions & 6.866 & $0.032^{*}$ & 4.604 & 0.100 \\
\hline Foreign Retailers & 2.895 & 0.235 & 5.056 & 0.079 \\
\hline Local Institutions & 4.399 & 0.110 & 4.851 & 0.088 \\
\hline Local Retailers & 7.484 & $0.023^{*}$ & 0.586 & 0.745 \\
\hline \multicolumn{5}{|l|}{ Panel C: Net Flows } \\
\hline Foreign Institutions & 11.774 & $0.002 * *$ & 9.243 & $0.009 * *$ \\
\hline Foreign Retailers & 12.525 & $0.001^{* *}$ & 10.004 & $0.006 * *$ \\
\hline Local Institutions & 2.879 & 0.237 & 2.847 & 0.240 \\
\hline Local Retailers & 5.905 & 0.052 & 2.403 & 0.300 \\
\hline
\end{tabular}

Note: ${ }^{* *}$ Significant at $1 \%$ level, $*$ Significant at $5 \%$ level. 
INTERNATIONAL JOURNAL OF ACADEMIC RESEARCH IN BUSINESS AND SOCIAL SCIENCES Vol. 8, No. 7, July 2018, E-ISSN: 2222-6990 @ 2018 HRMARS

The null hypothesis that 'net flows do not granger-cause market return' is also rejected for net flows of both foreign institutions and retailers at 1 percent significant level. These findings also provide evidence that there is a bidirectional causal relationship between market return and net flows of both foreign institutions and retailers. Prior study by Bekaert et al. (2002) provides evidence that capital flows affects return of Malaysian equity market on monthly basis. Hong and Lee (2011) also document similar findings. Their study shows that foreign and institutional investors net investment flows as well as government drive Korean market return. French (2011) however, finds no relations between net flows and returns of South Africa equity market.

\section{Relationship between Market Volatility and Equity Flows}

Table 5 presents the results of Granger causality test between market volatility and equity fund flows. Panel $A, B$ and $C$ report the results of causal relations between market volatility and equity flows in term of buy trades, sell trades and net flows respectively. The finding of this study demonstrates the null hypothesis that 'market volatility does not granger-cause equity flows' for buy trades of foreign institutions is rejected at $5 \%$ significant level. The finding indicates that market volatility has an impact on the buy trades of foreign institutional investors. Meanwhile the null hypothesis that 'market volatility does not granger-cause equity flows' for sell trades of all categories of investors is accepted at 5\% significant level. Prior study such as Paek and Ko (2014) reveal that past market volatility significantly and positively affect both inflows and outflows for the US market. Meanwhile, lagged market volatilities has insignificant (significant) negative effect on inflows (outflows) for the Japan equity market. The results in Panel $\mathrm{C}$ indicate the null hypothesis that 'market volatility does not granger-cause equity flows" is rejected for net flows of local retail investors at $1 \%$ significance level. Paek and Ko (2014) demonstrate that there is no impact of lagged market volatilities on net flows.

Meanwhile, the null hypothesis that "equity flow does not granger-cause market volatility" is accepted for the buy and sell trades; and net flows of all categories of investors even at 5 percent significant level, thus is not consistent with findings of prior studies. A study by Li and Wang (2010) demonstrate that institutional buy (sell) trades affect price volatility at the market level negatively (positively). Another study by Ahmed (2016) analyses the association between market volatility and flows of equity, both foreign and local investors on Qatar Stock Exchange. The findings of his study show that there is a positive impact of foreign institutions and individual sell trades on market volatility. On the other hand, foreign institutions buy trades have a negative impact on market volatility. Meanwhile, local institutions buy trades affect market volatility negatively but there is no impact for the sell trades of local institutional investors. Nguyen and Le (2013) examine the flowsmarket volatility relations on Vietnamese stock market. They find that there is a significant shortterm impact of past foreign flows on market volatility. The foreign flows-market volatility relation is stronger and significant in the bull market as compared to bear market for gross buy and sell; and gross net buy. Li and Wang (2010) demonstrate that there is significant and negative association between institutional buy-sell imbalance and price volatility; and it is due to unexpected component. Another study by Umuthu et al. (2013) show that foreign investors' net equity flows influence average total volatility in the Istanbul Stock Exchange. A study by Cao, Chang and Wang (2008) reveal that there is bidirectional relationship between mutual fund flows and market volatility. 
INTERNATIONAL JOURNAL OF ACADEMIC RESEARCH IN BUSINESS AND SOCIAL SCIENCES Vol. 8, No. 7, July 2018, E-ISSN: 2222-6990 @ 2018 HRMARS

Table 5. Granger-Causality Test between Market Volatility and Equity Flows

\begin{tabular}{lccccc}
\hline \multirow{2}{*}{ Equity Flows } & \multicolumn{2}{c}{$\begin{array}{c}\text { Market Volatility does not } \\
\text { Granger-cause Equity Flows }\end{array}$} & & \multicolumn{2}{c}{$\begin{array}{c}\text { Equity Flows does not } \\
\text { Granger-cause Market Volatility }\end{array}$} \\
\cline { 2 - 3 } Panel A: Buy Trades & Chi-sq & Prob. & & Chi-sq & Prob. \\
Foreign Institutions & & & & & \\
Foreign Retailers & 8.193 & $0.016^{*}$ & & 1.634 & 0.441 \\
Local Institutions & 1.025 & 0.598 & & 3.466 & 0.176 \\
Local Retailers & 2.198 & 0.333 & & 0.088 & 0.956 \\
& 4.595 & 0.100 & & 2.573 & 0.276 \\
Panel B: Sell Trades & & & & \\
Foreign Institutions & 4.063 & 0.131 & & 3.239 & 0.197 \\
Foreign Retailers & 2.409 & 0.299 & & 1.683 & 0.431 \\
Local Institutions & 0.618 & 0.734 & & 0.302 & 0.859 \\
Local Retailers & 4.303 & 0.116 & & 2.625 & 0.269 \\
& & & & \\
Panel C: Net Flows & & & & & \\
Foreign Institutions & 1.938 & 0.379 & & 2.112 & 0.347 \\
Foreign Retailers & 1.213 & 0.545 & & 2.406 & 0.300 \\
Local Institutions & 0.866 & 0.648 & & 0.411 & 0.814 \\
Local Retailers & 9.937 & $0.007^{* *}$ & & 1.318 & 0.517 \\
& & & & & \\
\hline
\end{tabular}

Note: $* *$ Significant at $1 \%$ level, * Significant at $5 \%$ level.

\section{Summary and Conclusions}

This study examines the dynamic linkages among market return, market volatility and equity flows of Malaysian stock market main investor groups. By using VAR approach, this study examines market return-flows and market volatility-flows causal relations, and vice versa. The results of VAR Granger causality test provide evidence of significant relationships between market return and buy trades of local investors, sell trades of foreign institutions and local retailer as well as net flows of foreign institutions and retailers. These findings show that the information content of earlier market returns is valuable to predict the trading behaviour of investors participate in local equity market (Ahmed, 2016). Meanwhile, equity flows affect market return for the buy trades of foreign retail investors, net flows of foreign institutions and retail investors categories. This study also finds evidence that market volatility is significantly impact the buy trades of foreign institutional investors and local retailer net flows of equity. In addition, the findings of this study also reveal that none of the equity flows influences market volatility.

This study contributes an understanding on the dynamic relationships among market return, market volatility and equity flows of Malaysia Stock Exchange. The results of this study can be used as guidance to various parties such as fund managers, institutional and retail investors, market speculators and policy makers to understand the investors' trading behaviour as well as to gauge the market sentiments. As Umuthu et al. (2013) states in their paper, it is very crucial to have an understanding on the costs and benefits of equity flows i.e. foreign equity investment in stock market as this matter has important policy implications. One of the costs that can arise is an increase in return volatility in emerging market brought by foreign equity investments. If this situation occurs, the policy 
INTERNATIONAL JOURNAL OF ACADEMIC RESEARCH IN BUSINESS AND SOCIAL SCIENCES

Vol. 8, No. 7, July 2018, E-ISSN: 2222-6990 @ 2018 HRMARS

makers have to develop ways to stabilise the stocks. This is because high volatility in local capital markets can impedes the growth and development of financial markets in the long run (Aimpichaimongkol and Padungsaksawasdi 2013). Thus, it is much easier to take necessary actions if they have a better understanding on the behavioural patterns of equity investors.

\section{Acknowledgement}

The author would like to thank Yayasan Tun Ismail Endowment Funds, Universiti Kebangsaan Malaysia for the financial support to conduct this research (Research grant \#: EP-2015-053 and Research Grant \# EP-2017-011).

\section{References}

Adaoglu, C. \& Katircioglu, S.T. (2013). Foreign investor flows and "blue chip" stock returns. International Journal of Emerging Markets, 8(2), 170-181.

Ahmed, Walid M.A. (2016). Cross-border equity flows and market volatility: the case of Qatar Exchange. International Journal of Emerging Markets, 11(3), 395-418.

Aimpichaimongkol, H. \& Padungsaksawasdi, C. (2013). Foreign Ownership and Stock Return Volatility: Evidence from Thailand. International Review of Business Research Papers, 9(5), 96-121.

Alexakis, C., Niarchos, N., Patra, T., \& Poshakwale, S. (2005). The dynamics between stock returns and mutual fund flows: Empirical evidence from the Greek market. International Review of Financial Analysis, 14, 559-569.

Aydogan, B., Vardar, G. \& Tunç, G. (2014). The interaction of mutual fund flows and stock returns: Evidence from the Turkish capital market. Ege Academic Review, 14(2), 163-173.

Bae, K. Yamada, T. and Ito, K. (2008). Interaction of investor trades and market volatility: evidence from the Tokyo Stock Exchange. Pacific-Basin Finance Journal, 16, 370-388.

Bekaert, G., Harvey, C. R., \& Lumsdaine, R. L. (2002). The dynamics of emerging market equity flows. Journal of International Money and Finance, 21, 295-350.

Ben-Rephael, A., Kandel, S., \& Wohl, A. (2011). The price pressure of aggregate mutual fund flows. Journal of Financial and Quantitative Analysis, 46(2), 585-603.

Bohn, H. \& Tesar, L.L. (1996). U.S. Equity investment in foreign markets: Portfolio rebalancing or return chasing? AEA Papers and Proceedings, 86(2), 77-81.

Cao, C., Chang, E. C., \& Wang, Y. (2008). An empirical analysis of the dynamic relationship between mutual fund flow and market return volatility. Journal of Banking and Finance, 32, 2111-2123.

Caporale, G. M., Philippas, N. \& Pittis, N. (2004). Feedbacks between mutual fund flows and security returns: evidence from the Greek capital market. Applied Financial Economics, 14, 981-989.

Cha, H. J. \& Kim, J. (2010). Stock returns and aggregate mutual fund flows: a system approach. Applied Financial Economics, 20, 1493-1498.

Chandra, A. (2012). Cause and effect between Fll trading behaviour and stock market returns: The Indian experience. Journal of Indian Business Research, 4(4), 286-300.

Dahlquist, M. \& Robertsson, G. (2004). A note on foreigners' trading and price effects across firms. Journal of Banking \& Finance, 28, 615-632.

Darwish, M. (2012). Testing the contemporaneous and causal relationship between trading volume and return in the Palestine Exchange. International Journal of Economics and Finance, 4(4), 182-192.

Dickey, D. A., \& Fuller, W. A. (1979). Distribution of the estimators for autoregressive time series with a unit root. Journal of the American Statistical Association, 74(366), 427-431. 
INTERNATIONAL JOURNAL OF ACADEMIC RESEARCH IN BUSINESS AND SOCIAL SCIENCES

Vol. 8, No. 7, July 2018, E-ISSN: 2222-6990 @ 2018 HRMARS

Dickey, D. A., \& Fuller, W. A. (1981). Likelihood ratio statistics for autoregressive time series with a unit root. Econometrica 49(4), 1057-1072.

Edelen, R. M., \& Warner, J. B. (2001). Aggregate price effects of institutional trading: A study of mutual fund flow and market returns. Journal of Financial Economics, 59, 195-220.

French, J.J. (2011). The Dynamic Interaction Between Foreign Equity Flows and Returns: Evidence from The Johannesburg Stock Exchange. The International Journal of Business and Finance Research, 5(4), 45-56.

French, J. J., \& Li, W.-X. (2012). A note on US institutional equity flows to Brazil. Review of Accounting and Finance, 11(3), 298-314.

French, J. J., \& Naka, A. (2013). Dynamic relationships among equity flows, equity returns and dividends: Behavior of U.S. investors in China and India. Global Finance Journal, 24, 13-29.

Froot, K. A., \& Ramadorai, T. (2008). Institutional portfolio flows and international investments. The Review of Financial Studies, 21(2), 937-971.

Froot, K. A., Connell, P. G. J. O., \& Seasholes, M. S. (2001). The portfolio flows of international investors. Journal of Financial Economics, 59, 151-193.

Giles, D. E. (2008). Some properties of absolute returns as a proxy for volatility. Applied Financial Economics Letters, 4(5), 347-350.

Grouard, M. H., Levy, S. \& Lubochinsky, C. (2003). Stock market volatility: from empirical data to their interpretation. Financial Stability Review, 57-74.

Ha, Y., Lee, B.S., Paek, M. \& Ko, K. (2015). Structural VAR Approach to Mutual Fund Cash Flows: Net Flows, Inflows, and Outflows. Asia-Pacific Journal of Financial Studies, 44, 59-87.

Hong, G. \& Lee, B.S. (2011). The trading behavior and price impact of foreign, institutional, individual investors and government: Evidence from Korean equity market. Japan and the World Economy, 23, 273-287.

Jinjarak, Y., Wongswan, J. \& Zheng, H. (2011). International fund investment and local market returns. Journal of Banking \& Finance, 35, 572-587.

Kim, JB., \& Kim, J. M. (2016). Stock returns and mutual fund flows in the Korean financial market: A system approach. BOK Working Paper No.2016-3, 1-25.

Lee, B. S., Paek, M., Hab, Y. \& Ko, K. (2015). The dynamics of market volatility, market return, and equity fund flow: International evidence. International Review of Economics and Finance, 35, 214-227.

Li, W. \& Wang, S.S. (2010). Daily institutional trades and stock price volatility in a retail investor dominated emerging market. Journal of Financial Markets, 13, 448-474.

Lin, A.Y. (2006). Has the Asian crisis changed the role of foreign investors in emerging equity markets: Taiwan's experience. International Review of Economics and Finance, 15, 364-382.

Lin, A.Y. \& Swanson, P.E. (2004). International equity flows and developing markets: The Asian financial market crisis revisited. Journal of International Financial Markets, Institutions and Money, 14, 55-73.

Lin, A.Y. \& Swanson, P.E. (2008). U.S. investors and global equity markets. International Review of Financial Analysis, 17, 83-107.

Mishra, P. K. (2011). Mutual funds investment flow and stock market returns in India. Vision, 15(1), 31-40.

Nguyen, L. \& Le, N. (2013). Impact of Foreign Portfolio Flows on Stock Market Volatility - Evidence from Vietnam. Journal of Emerging Issues in Economics, Finance and Banking, 2(5), 872-887. 
INTERNATIONAL JOURNAL OF ACADEMIC RESEARCH IN BUSINESS AND SOCIAL SCIENCES

Vol. 8, No. 7, July 2018, E-ISSN: 2222-6990 @ 2018 HRMARS

Paek, M. \& Ko, Kwangsoo. (2014). Aggregate net flows, inflows, and outflows of equity funds: The U.S. versus Japan. Japan and the World Economy, 32, 85-95.

Pavabutr, P. \& Yan, H. (2007). The Impact of Foreign Portfolio Flows on Emerging Market Volatility: Evidence from Thailand. Australian Journal of Management, 32(2), 345-368.

Oh, N. Y., \& Parwada J. T. (2007). Relations between mutual fund flows and stock market returns in Korea. Journal of International Financial Markets, Institutions and Money, 17, 140-151.

Richard, A. (2005). Big Fish in Small Ponds: The Trading Behavior and Price Impact of Foreign Investors in Asian Emerging Equity Markets. The Journal of Financial and Quantitative Analysis, 40(1), 1-27.

Sapian, R.Z.Z. \& Auzairy N.A. (2015). Foreign Equity Flows and Market Return Linkages: Evidence of Malaysian Stock Market. Global Business Review, 16(5S), 1S-14S.

Ülkü, N. \& İkizlerli D. (2012). The interaction between foreigners' trading and emerging stock returns: Evidence from Turkey. Emerging Markets Review, 13, 381-409.

Umutlu, M., Akdeniz, L., \& Altay-Salih, A. (2013). Foreign equity trading and average stock-return volatility. The World Economy, 36, 1209-1228.

Wang, J. (2007). Foreign equity trading and emerging market volatility: Evidence from Indonesia and Thailand. Journal of Development Economics, 84, 798-811.

Warther, V. A. (1995). Aggregate mutual fund flows and security returns. Journal of Financial Economics, 39, 209-235.

Watson, J., \& Wickramanayake, J. (2012). The relationship between aggregate managed fund flows and share market returns in Australia. Journal of International Financial Markets, Institutions and Money, 22, 451-472. 